\title{
The Indoctrination and the Treatment of Children from ISIS
}

\author{
Dr. Dounia Bouzar ${ }^{\star, \dagger}, 1$, Michel Bénézech ${ }^{2}$
}

${ }^{1}$ Paris, France.
${ }^{2}$ Bordeaux, France

D DOI: https://doi.org/10.15520/jcmro.v2i06.169

Accepted 05-06-2019; Received 25-05-2019; Publish Online 05-06-2019

Reviewed By: DR.

KINGSLEY

Department:

Reviewer/CMRO

\begin{abstract}
Islamic State of Iraq and Sham (ISIS) use the most elaborate technological ways of our time to consolidate a new propaganda. We will see how kinship with Nazism makes it possible to observe similarities in the mechanisms used to spread propaganda. Some aspects also cut across the techniques used on child soldiers.

Our study shows that the whole process of juvenile indoctrination results from the interaction of tree cumulative approaches:
\end{abstract}

- Emotional (ISIS has an anxiety-provoking approach, based on the exacerbation of the fear of "the others"),

- Relational (the group becomes a substituted family where the bonds are fusional and protective, the child distances himself from his kinship system to regenerate through a new imaginary filiation, sacred and fantasized)

- And cognitive-ideological (the discourse presents the application of the divine law to obtain a better self and a better world.

Based on a follow-up of 450 French jihadists from 12 to 25 years old as part of a ministerial mission, first lines for treatment will be shared, especially by reflecting on the consideration of the trauma and on the role of the extended family. The conceptual framework for the dis-indoctrination program of children must integrate a two-fold emotional-ideological dimension.

Key words: Children, ISIS, Indoctrination, Dis-Indoctrination, Jihadisme, Treatment.

\section{INTRODUCTION:}

The use of child-fighters has not started with Islamic State of Iraq and Sham (ISIS) and is not a "jihadism's" feature. On the contrary, the use of underage is a frequent thing in the war History and can be observed beyond Syria and Iraq. This role of child-fighters has been repeated again and again in the History (for example the "Marie-Louise" in France under Napoleon at the beginning of the $20^{\text {th }}$ century) and has grown throughout the $20^{t h}$ and $21^{s t}$ centuries to reach its modern peak with the terrorist group ISIS. But contemporary terrorists' groups use the most elaborate technological ways of our time to consolidate a new propaganda

\footnotetext{
* Corresponding author.

$\dagger$ Email: dounia.bouzar@gmail.com
}

shape, such as internet, video games, phone applications, videos, etc. There is a consensus among researchers about this topic [1-6].

We will see that "the kinship between totalitarian regimes" [7] allows to observe similarities in the mechanisms used to disseminate propaganda, but also in the objectives. Some aspects also intersect with the techniques used on child soldiers [8] . If ISIS is not, strictly speaking, a rebel group, an army or a new Nazi form, it knows how to take back techniques already proven in history.

Talking about children from ISIS is a subject encompassing very different situations. First, we must understand that children are used both as bait (photos symbolizing the rebirth based on purity to phish the utopians [4] or guilt photos of dying babies to phish the humanists) and as recruitment goals (generation that will take over) [9]. 
There is a diverse targeting of those who are recruited. Must be distinguished:

- European children indoctrinated by their parents

- those kidnapped by one of their parents without the knowledge of the other,

- those indoctrinated directly by ISIS, via social networks, from the age of 12 .

- Concerning the Syrian or Iraqi children, there is also:

- the children kidnapped by ISIS (children raid mostly of Yezidi tribes, but not only)

- the children enlisted by ISIS (ISIS promises them to meet their needs and those of their families).

Once inside ISIS, the missions of the children are diversified. We resume the classification made by the Quilliam foundation [8]. Children can become spies, preachers, "poets", "cleaners", soldiers or kamikazes.

ISIS is a new product that has capitalized former processes, developed and tested by other totalitarian ideologies. We will see how this deploys their indoctrination and several experiments to organize their disindoctrination.

\section{METHODOLOGY:}

\subsection{Sample:}

This article is based on the follow-up experience of 450 young French people who tried to join ISIS or tried to commit an attack on French soil between 2014 and 2016. They are between 12 and 25 years old. They were followed for two years by a multidisciplinary team, in the framework of a ministerial mission (Circulaire INTA 1512017J du 20 mai 2015). Qualitatively and quantitatively, we explored their micro and macro characteristics. We have also eliminated the risk and protective factors that may facilitate their disengagement from violent extremism $[10,11]$.

\subsection{Data Collection:}

There are two types of data:

- Individual and collective data gathered through the follow-up conducted by the center of prevention against sectarian drifts related to Islam (Centre de Prévention contre les Dérives Sectaires liées à l'Islam : CPDSI. This data has been collected from their discourses in the context of our disengagement programme. It consists in a gathering of semi-directive and non-directive individual interviews with the youngsters and their families, as well as collective semidirective interviews as part of a talking group. In the majority of cases, communications on social networks from their computer and cellphones could have been exploited by the CPDSI multidisciplinary team (thanks to the trustful relationship of close relatives who asked for our help, or sometimes directly provided by the radicalized one at the end of his/her follow-up). Viewed and shared videos have also been analyzed.

- "Implicit data" giving access to ideals and promises of the "jihadist" discourse luring youngsters during their radicalization process. Individuals responding to the "jihadist" offer do not necessarily raise awareness regarding those elements, and this is the reason why they do not express them explicitly once interviewed. To access these implicit data, we based our work on, but not limited to, the study of recordings of conversations between recruiters and youngsters, the arguments used, the videos shared, as well as the analysis of the individuals' life phases, their ideals before being radicalized, the traumatic elements they have experienced, and the conversations with their relatives.

In other words, we have been collecting data on what has originally conditioned the engagement of the young people that have been monitored, starting from the assumption that "to become authoritative, a discourse must make sense" [12]. We could do so because we have followed them up on an average duration of two years. In addition, we had access, thanks to families' participation, to data on their conversations and personal stories.

\subsection{Data Analysis:}

To apprehend the radicalization process (and its exit) of the 450 youngsters of our sample, we conducted a study based on a qualitative social anthropological approach [13].

It consists in a thematic analysis of the data collected through our assistance programme to study the steps of the radicalization process and categorize the different commitment motives $[14,15]$. The use of a qualitative thematic approach can widely be explained by the context of intervention of the CPDSI. Indeed, the access to these unpublished data allowed a deconstruction of every individual journey at both explicit and implicit level. This approach is based on anthropology and enhanced with other social sciences (psychology, sociology, geopolitics, history). It allows to understand how "radicalized" individuals welcomed the "jihadist" ideology, and how they have changed their behaviors and cognition over the process of radicalization. This research does not seek to find an explanation to the "jihadist" phenomenon nor to an individual becoming a "jihadist", but instead to suggest a comprehension of their paths.

\section{STAGES OF THE INDOCTRINATION PRO-} CESS:

Their indoctrination includes a mix of emotional, relational, and ideological approaches. He changes their vision of the world and teaches them to be wary of "Others". He ends with training camp, to put into practice what they learned during the indoctrination.

3.1 - An emotional and relational approach of indoctrination

For children, the emotional approach goes through a new father figure: "The common point of totalitarian dictatorship leaders is to present themselves as natural leaders who 
will save the world with a disruptive ideology that claims utopia (new city) in uchronia (new era). (...)" [16] . But the ISIS's leader has it on both ways, profane and sacred. Once he has manipulated history and memory to become a providential man, he will at the same time evoke the Muslim ethic that does not allow to divinize a leader (which would make him an idol and so would violate the sacred principle of Unity of God / "Tawhid") and adopt a strategy where he glorifies only God. This is the big difference between the ISIS's totalitarianism and other political ideologies: it is not the superiority of the race that determines who "possess the Truth" but the superiority of the good interpretation of the divine word, granting all power increased tenfold. The leader appropriates the omnipotence of God by pretending to act in His name.

At the relational level, the search for a peer group by children escaped neither the notice of Nazis nor of the ISIS's leaders. Enlistment in a totalitarian ideology always includes a sectarian dimension leading the individual to a kind of disaffiliation if the family is not radicalized too. This is what we have called "relational recruitment" in our studies about the young "jihadists" [17] from their testimonials, here is an excerpt : "I was very attached to them, I needed their presence, it was as if I had become addicted, (...) I had the feeling they were my sisters, that we were the same, that my place was there, near them. (...) They had become my family, my brothers, my sisters, they protected me against the outside world, against myself " [18].

\section{2 -To regenerate by regenerating society}

The idea that renewal comes through the destruction of the past is not new. This goal of regeneration is found in all totalitarian ideologies. It removes the old emotional, memorial and historical references of individuals, in order to standardize them and lead them to no longer think, so they follow the path of their new group. Having the feeling of being similar accentuates the fusion within the group. The identity of the group supersedes the individual identity. Each totalitarian group accentuates the physical similarities between the members of the group to increase the feeling of being "the same": hair dyed in black, uniform, clothing that destroys the identity contours, destruction of personal objects, etc.

Watch the video $\mathrm{n}^{\circ} 1$ of ISIS by clicking on this link $=>$ https://vimeo.com/285625417

Traduction du chant :

"(...) We came as soldiers of God,

We walked out of love for God (chorus).

We sing a religion that we revivify

We are building a building that we are building

We eradicate a humiliation we have tasted

We put an end to a state of tyranny (...)".

The regeneration of Man and the world, already brandished by secular totalitarianism, is all the more advocated by this totalitarianism, which claims to be inspired by God. Since its emergence, the "jihadist's" line promises the regeneration of the world and of men by replacing the human law by the divine law. According to their totalitarian ideology, only their interpreted divine law can manage a society perfectly. To fight against arbitrariness and corruption, they must get rid of everything that has a link with the human, which hinders the purity of the divine.

But unlike secular totalitarianism, it is not a matter of creating a new world but of returning to an idyllic past. It means that the use of Islam in the "Jihadist's" project of "regeneration of Man and the world" includes two different registers:

- the divine law is presented as an absolute truth because it would be the Divine Word and the human dimension of any religious interpretation (historical, anthropological and political) is denied;

- a pathogenic relation to the past, where religion is a means and a pretext for creating an apologetic story of Muslim History (as if there were no distinction between a religious system and historical processes, hence the immense work of the Franco-Algerian anthropologist, Mohammed Arkoun, who wanted to distinguish the religious ideal from historical forms in which it has been implemented, both in terms of representations and political practices.) The "jihadist's" line considers that each historical step and / or human construction marks a distance from the "true message" of Islam and therefore wants to get back to the "initial point".

3.3 - Inspire a sense of persecution in order to claim self-defense

The feeling of persecution plays a predominant role because it will justify the use of violence to defend themselves. It is part of the stressful emotional approach that initiates any radicalization process, to the extent that the "jihadist's" line wants to lead the young people to be wary of anyone outside the radical group and to invest the radical group as the only reassuring area. At this point, the radical line proposes compensatory dysfunctional solutions that are supposed to represent "the way out" of the stressful situation. The indoctrination therefore goes through the "fear of the Other", the one that does not belong to the radical group.

In summary, like the adult, the child is immersed in a paranoid worldview, where he/she must be wary of all those who are designated as responsible for the "evil". In a comprehensive treaty regarding extremist groups in the United States, Hofstadter used the notion of 'paranoid style' to characterize their thoughts and behaviors [19]. Aaron Beck emphasizes that the development of a paranoid personality is quite inevitable when part of a group that built a collective identity based on a vulnerability vis-à-vis a controlling and intrusive government (in other words: 'a government that applies human laws' according to Islamist radicals) [20]. He notes that "as paranoid delusions, the paranoid perspective focuses on the enemy and their 'plot'. The conflict escalation with the persecutor exacerbates the paranoid position. As the extremist, the paranoid patient will attack his alleged persecutors. The militiamen who perceive themselves as oppressed by the agencies of a tyrannical government will retaliate against their alleged enemies" [20]. The common characteristic between paranoid patients and members of extremist groups is the presence of "an enormous psychological investment in their believes both grandiose and persecutory: 'we can save the world, we can overthrow the tyrannical government" [20]. 
Watch the video $\mathrm{n}^{\circ} 2$ of ISIS by clicking on this link $=>$ https://vimeo.com/285626324

This view strengthens the fusion within the group and the isolation vis-à-vis the rest of the world. Any group wary of the outside falls back automatically and naturally on itself. The feeling of persecution is used in all totalitarian ideologies among children as well as among adults.

The radical line gradually urges to hate all those who do not make allegiance to it, so those who have another analysis of the situation and / or those who choose other alternative solutions than group's solutions. At this stage, the radicalized-one is convinced to have discernment, to possess "the Truth" and rejects those considered asleep or accomplices of the enemies. He/she has a binary worldview, with good people on one side and bad people on the other. The videos show that the younger the child is, the more the emotional stressful approach will go through emotional register, convincing the child that he/she must avenge his/her parents ...

\section{4 - The trivialization of violence at school}

These so-called areas of schooling are the perfect places for children's indoctrination. School is the incubator stage for totalitarian ideology, before the training camp, formatted to relay the ISIS's ideology. Like the "Nazi-Germany", subjects that do not contribute to the ideology's development have been removed from the "education" imposed by ISIS. From the first years of schooling, the goal is to transmit the totalitarian ideology to children by developing a universe and a warlike lexical, by using books similar to the ones used by the Hitler's youth, here in color. The same exercises are proposed in ISIS's "textbooks", than in Nazi's books, accustoming the child to an omnipresent warrior and murder environment. We find in all the textbooks, published by ISIS, the same process of militarization than we find in the Nazi's textbooks.

Children are noticeably trained at the same age (between 5 and 8 years old), but ISIS goes further on the propagation of the ideology in terms of technical and technological means (videos for children, video games, etc.) The "jihadist's" indoctrination process is strengthened by the support of the digital since it proposes applications for computer and telephone, for very young children in order to learn letters. These applications rely on the child universe and is mixed with violence in order to sublimate it.

It is not about raising a new generation of people involved in creating an ideal society in Syria or Iraq, as the recruiters dangle it, but to create a generation of fanatical fighters able to kill all those who would not submit to their project. To prevent children from escaping indoctrination, home schooling has been banned by ISIS.

3.5 - The glorification of the dead by pictures and songs

The role of the visual through media and culture has been heavily invested by totalitarian regimes. Brain imaging studies indicate that information received through images, as opposed to texts, tend to elicit faster and stronger emotionally responses. Both channels (image and text) engage different models of cognitive processing. The more the convictions go with a strong emotional charge, the more they are permeated. The less complex the information is, the easier it is memorized.

The precursors of this propaganda's tool via images are the Nazis. They are the first to include war dead worship in their propaganda media for new generation of future soldiers conditioned to blindly obey to the Führer.

Like the Nazis, the "jihadists" have taken an additional step thanks to the mastery of current communication tools, including of course the Internet and social networks. Among the Nazis, the cult of the dead was instilled through textbooks or films, but the Hollywood look alike audiovisual production of ISIS has made possible to take a step in the veneration of soldiers who died as martyrs for the "cause". These productions are presented on the Internet to all supporters, including to children from ISIS.

\section{6 - Children's training camps}

The training camp for children is the place of concrete implementation of the totalitarian ideology. This is where the level of emotional disorganization that allows one to face death must be tested. This training replaces what we have called "the individualization of recruitment" carried out by recruiters via Internet on teenagers and young adults when they are in France. We describe meticulously this process where recruiters adapt the "jihadist" ideology to the cognitive and emotional aspirations of each teenager, to convince him/her to join the group and the "jihadist" project [15].

They use the needs and ideals of each young person to offer him/her a promise that makes sense and authority on him/her, so to make him/her then climb the steps of the radicalization's process.

For childrens, enlistment therefore takes place more by common training. In all totalitarian movements, the functioning of camps is based on the idea of redefining the boundaries between the private sphere and the public sphere of each child, until there is nothing left of the first. The child should no longer have rights outside the interests of the group. He/she must no longer have personal time or private space. The laws of the group invade the private until there is nothing left of the individual. It is on this condition that children may be exposed, in a manner assumed and claimed, to the violence.

Bénézech \& Estano recall that "In addition to a focus on individual psychology, the psychology of groups would be relevant to understand the processes of radicalization" [21]. They also recall in 2016 that "For Freud, the crowd allows the psychic regression of individuals in the mass, decreases the repression of unconscious tendencies, eliminates moral inhibitions. Instinct and affectivity then expressing itself more intensely "[22]. Various researches have proved the influence of the group in the acting out: Stanley Milgram's experiments have shown that situational factors - such as the presence of a person with authority, or the fear of losing a relationship within the group - can influence [23, 24]. Solomon Asch showed that the members changed their judgment to conform to that of their group [25]. Christopher R. Browning's study of the Nazis also discusses the importance of the group: « To refuse to kill meant to break a tacit 


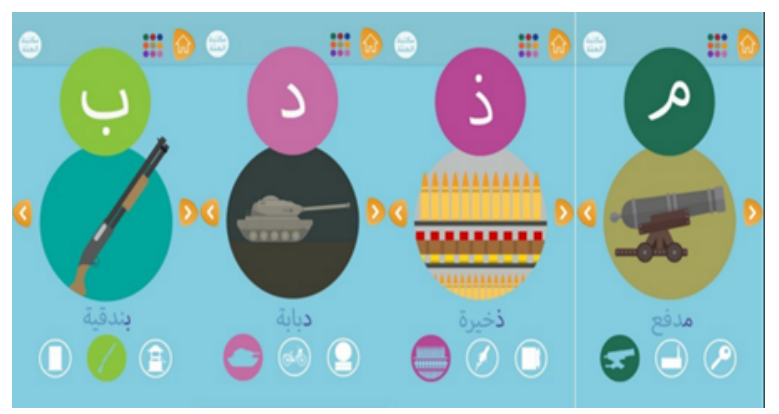

Figure 1. Exemple of school notebook

agreement of solidarity between men belonging to the same battalion - which was akin to treason» [26] [26 p 125].

The common goal (called "self-defense" or "resistance") will encompass the entity of the psyche and affects, leading to a kind of double dehumanization: of the child and of his/her future victims:

Dehumanization of oneself: in all totalitarian groups, indoctrination tries to lead children to perceive human bond as an evidence of weakness or fragility, including with their own parents. Gradually, they reject all the feelings that constitute the human being. But until then, ideology denied the child as a thinking being. From training in the camps, ideology denies the child as a living being, for the benefit of the ideology. In other words, he will harden and feel nothing. During the ISIS's training, the child gets blow to be used to the pain. The hardened child ends up identifying himself/herself to the group's cause and only exists through it, even if he/she has to kill or to be killed for it.

Watch the video $\mathrm{n}^{\circ} 3$ of ISIS by clicking on this link $=>$ https://vimeo.com/285561673

Dehumanization of others: Children are not just trained to kill all who do not belong to their group, they teach them to dehumanize victims in order to facilitate their killing. The one who has been designated as "Enemy" no longer appears as an ally but as a simple thing, and so everything is allowed without any feeling of guilt. This dehumanization can occur with the way of naming the Other - "they squeak like pigs when they are afraid" - but it can also be done by dismembering dead bodies, in order to eliminate their human appearance [8 p36]. Generally, children are trained to sadism by practicing on animals. It is obvious that the care for a child who has gone through a training camp is different of the care for a child who has "just" been indoctrinated at school, because he/she has known the extreme violence. $\mathrm{He} /$ she has experienced trauma but has also developed a paranoid perception of the world that will lead him/her to develop violent behavior.

The difference between the child-fighter and the child indoctrinated by a totalitarian ideology lies in the fact that the first one can be dehumanized by a dehumanizing treatment, while the second, if he/she can undergo the same kind of dehumanizing training, is also "educated" in an ideology that gives him/her a kind of justification for violence. It is not possible to claim that a child "adheres" to this justification, but it offers a kind of world's grid of reading defining a logic in which he/she is immersed. Conversely, some child soldiers are enlisted with any ideology and suffer such violence that they become violent only to survive.

Watch the video $\mathrm{n}^{\circ} 4$ of ISIS by clicking on this link $=>$ https://vimeo.com/285627214

\section{CONDITION OF THE INDOCTRINATED CHILDREN, RECOVERY AND RECONSTRUC- TION:}

Even if ISIS was inspired by children's recruitment methods initiated by other modern totalitarian groups, we cannot compare the care of children indoctrinated and / or enlisted by the "jihadist" group to child soldiers or Nazi children. In fact, a life-threatening situation characterizes the recruitment of child soldiers, who often fight to not starve or to prevent their families from being killed. Their dehumanization is more the product of combat training than the result of an elaborate ideological process. Programs that support child soldiers are dedicated to their professional training and the search for their families (to precede their reunification). And for the Nazi children, the geopolitical context was different: they were enlisted by governmental authorities and not by a small terrorist group which is opposed to the authorities of the state. Their dehumanization was the product of their ideology that considers the Jew, Gypsies and Homosexuals extermination as the condition to regenerate society, but this last one was spread by political authorities of the State. That being said, there are nevertheless similarities between these child combatants, particularly the relation to trauma. To reintegrate them, we must take into account the collective trauma of nations that have suffered attacks. It is unfortunate that the legal framework does not consider all child combatants the same. This would help their care.

\subsection{The traumas of the child related to a terror- ist group, are identical to the traumas of child- soldiers:}

Can we consider that children involved in terrorism have a similar status than child-soldiers or children enlisted in other totalitarian ideologies? The report "Children and counter-terrorism", made by the United Nations Interregional Crime and Justice Research Institute (UNICRI), 
from 2016, points out that there is "a striking dissonance between the approach taken for children involved in terrorism and the approach taken for child soldiers in armed conflict. Child fighters are widely treated as victims and are not prosecutable, and international law recognizes their need for rehabilitation and reintegration. While children involved or engaged in activities related to terrorism are likely prosecutable and can have long prison sentences. Yet, in some cases, the difference between the child soldier and the child involved in terrorism is not very obvious" [27].

This is the case of psycho-trauma experienced by these children in an identical way. All the children who lived in the ISIS zone do not come back traumatized because some of them have, despite everything, been protected by their parents. But knowing how to diagnose trauma of children returning from a war zone is essential to their care, especially since they are all brutally separated from their mother when they land at the airport. While parents are detained, the assessment of their physical and mental health is immediately made at their arrival, knowing that the trauma suffered by children goes beyond physical injury and the danger of death related to war zones. The observations made following the first returns of children from ISIS show different kind of traumas.

It therefore seems essential that social workers who take care of children from ISIS can diagnose and recognize trauma [28].

This is fundamental for two main reasons:

- The child who has suffered trauma usually does not remember it and develops symptoms that can be misunderstood and badly treated.

- The support of the minors will consist in reassuring them about their entourage whom they learned to consider as their "Enemy". They must learn to trust the human and gradually society and its democratic system based on human laws. Children arrive with a double handicap: an ideology that has taught them to be wary of "Others" and a possible trauma that has made them lose faith in adults. The feeling of paranoia caused by a trauma adds to the feeling of paranoia caused by indoctrination.

- There is also a third dimension we can add to the first ones: the brutal separation from the mother can also be traumatic.

\section{2 - To consider the national trauma}

The first thing to do with these children is to re-socialize them as soon as possible. But the DDR programs (Disarmament, Demobilization, Reinsertion) for child soldiers [29] and the RAN [28] explain that the first global obstacle of this rehabilitation path is the stigmatization of these children by traumatized societies, particularly in France because of the recent attacks.

To ignore that point would be counterproductive, because the rejection that will live those "terrorism's indoctrination victims" can revive their distrust and anxiety. When teenagers or young adults recognize that they made a mistake and want to involve on prevention to prevent their peers from joining ISIS too, society is not ready to accept their repentance. Children from ISIS are only seen as the future generation that will take the ideological succession as double agents, conditioned and locked in this ideology forever. This is the caricature of the famous motto "terrorist someday, terrorist forever".

Terrorist actions affect the individual and society in a multidimensional way. They damage individual values and freedoms and go with what is called in psychology the" loss of identity feeling" and the "random death. The society attacked by radicalism, become radicalized too.

Terrorist actions affect the individual and society in a multidimensional way. They damage individual values and freedoms and goes with what is called in psychology the" loss of identity feeling" and the "random death", the society attacked by radicalism, become radicalized.

The RAN states that this dimension cannot be hidden in order to guarantee the rehabilitation of children [28]. Rehabilitation must be put back in a social context that considers both the trauma of the community and the individual trauma of the child. Especially since it also changes how the social worker is seen: he/she will not be perceived the same way if he/she takes care of an abused child or a child coming back from ISIS. He/she must be aware of the collective trauma and the way in which it impacts his/her own representations and representations of his/her relatives. The stigmatization of these children may lead some policy makers to lock up this people in the same place with many other radicalized young people, which will only encourage them to mistrust the society again and to feel melancholy of the former fusion within the group, whereas it comes to confronting them individually with other worldviews so they can question the indoctrination received within ISIS.

This post-attack reaction is completely anticipated by the "jihadist" thinkers and far right ones. It strengthens amalgams inducing discriminations too against Muslims and Arab people. The "jihadist's" line needs hatred against Muslims to justify its own hatred. Discrimination against Muslims and Islamophobic lines strengthen ISIS, to the extent that they validate its vision of the conspiracy against Islam.

It therefore seems important for social workers to be aware of the interactive issues beyond them to take care of this generation of children who are traditionally called the "sacrificed-ones" but who are still lucky enough to be alive and able to change their deadly destiny.

\section{3 - To consider the legal framework}

The social worker works within the legal framework. His/her activity is a sort of contract that society entrusts to him/her and his/her position puts him/her at the crossroads of several disciplines: psychology, sociology, law, etc. The legal framework is all the more important to know that it reflects the evolution of society on how to apprehend the human, and in this case the child and the minor.

The article 19 of the International Convention concerning child rights signed in 1989, prohibits all forms of violence against children, including any physical or mental violence, intentional or not, as well as any abuse [30]. States present at the Convention have agreed to take measures to promote the physical and psychological recovery and reintegration 
of witnesses and child victims in their respective societies. This obligation arises from Article 39 of the Convention and applies to support and assistance measures in general and to criminal prosecution in particular. Child witnesses are generally considered as victims of the crime (s) they have witnessed, even if they do not have this technical legal status in legal proceedings. Thus, both witnesses and child victims in contact with the judicial system enjoy protection. In addition, Article 38 requires member States to take all possible measures to ensure the protection of children affected by armed conflict. Children recruited and exploited by violent extremist and terrorist groups may also be victims of violence considered by the optional Protocols of the Convention on child Rights, including by the optional Protocol about the involvement of children in armed conflicts, the Article 4 of this Protocol states that recruitment and exploitation of children by non-State armed groups in hostilities, is totally forbidden. For its part, Chapter I, Section C, Article 4, paragraph 3 of Protocol II of the Geneva Conventions, prohibits the recruitment of children under the age of 15 , by non-State armed groups [31] . The article 4 of the optional Protocol of the Convention on Child Rights about the involvement of children in armed conflict has a broader definition as it considers children under 18 years old [32].

The words "terrorist groups" and "extremist violent groups" have only vaguely been defined by law and United Nations ask "Member States to define them in accordance with their international obligations" in the field of Human Rights [27]. A criticism was made about this lack of definition and therefore the lack of impact that recommendations and obligations linked to this phenomenon may have, since the phenomenon itself is ill-defined. This may partly explain the difference in treatment between the child-terrorist and the child soldier.

The report "Children and counter-terrorism" [27] recalls that the line of the special representative of the Secretary-General about children and Armed Conflict and by many NGOs is that children under 18 recruited by groups, whether by force or voluntary, whether they are active combatants or just having a supporting role, should not be prosecuted for membership or for acts as combatants [33], but should be reintegrated and rehabilitated through a range of different rehabilitation justice programs. The rapport "Children and Justice During and in the Aftermath of Armed Conflict" goes further and urges governments to ensure that any child arrested for security reasons is treated primarily as a victim [33].

The UNICRI report "Children and counter-terrorism" notes that there is a big difference in treatment between "terrorist children" enlisted by terrorist's groups and child soldiers, who can also be used as kamikazes, porters, spies, messengers, watchers or even sex slaves [27]. Yet, as the RAN report points out: "Just like child soldiers, children returning to their country of origin can be considered as victims and, in some cases, also as perpetrators of violence at the same time" [28] [28 p 99]. The report insists on the fact that in many cases it is extremely difficult to distinguish the difference between child soldiers and terrorist children, at the conceptual, factual and legal levels. In fact, some children will be treated as "terrorism's suspects" simply because governments, with or without international support, designate armed groups as "terrorists" [34] .

\section{SUPPORT OF ENDOCTRINATED CHIL- DREN AND REHABILITATION:}

The RAN proposes to distinguish the follow-up of the under-12s and that of the over-12s. In any case, the family is a precious help. If the parents are radicalized, the extended family can be associated because it will be easier to re-affiliate and re-nationalize the indoctrinated child.

\subsection{The care of children over 12 years old goes through the acknowledgement of their share of victimhood and share of responsibility:}

The thinking of the Quilliam Foundation [8] and those of the child-soldier specialist Mouzayan Osseiran-Houballah [35] go in the same direction as ours, following our experience over 12-18 years old recovery [17] . The release of radicalization cannot begin without having previously accompanied the radicalized-one capable of discernment in the awareness of his/her responsibility.

We have been able to check that, if he/she has not recognized "his/her share of victimhood", the minor cannot be held responsible for his/her actions, because the recognition of his/her responsibility must go through the recognition of the responsibility of the person who has hurt him/her where appropriate. And if he/she has not recognized "his/her share of responsibility", he/she cannot be a victim. One does not go without the other. Very often, and especially in adolescence, being able to see oneself as an author first of all means being able to establish oneself as a victim and vice versa. The radicalized minor, both author and victim, must recognize both his/her share of "victimhood" and his/her share of responsibility.

There are two "victimhood's" dimensions:

-the radicalized-one must recognize that he/she has been manipulated by the radical group;

-he/she must also be aware that his/her previous vulnerabilities and / or traumas have made this manipulation easier...

According to our feedback [11], most of the young people who have been then radicalized had all experienced untreated and / or non-conscious trauma in their early childhood.

The social worker must remember that some trauma patients do not remember their trauma and develop some strategies to forget, to protect themselves. There can be several kinds of trauma, which can be added together:

- a trauma that occurred during infancy, which had not been treated and "discussed": let recall the statistics of the young people we have followed, from 12 to 25 years old [11]:

$73 \%$ of young people report having experienced a symbolic or real abandonment; 
. $70 \%$ have experienced severe trauma or psychological abuse;

. $48 \%$ were qualified "depressed" by medicals;

. $35 \%$ were treated by a psychologist;

. $32.5 \%$ had cut themselves or attempted suicide;

. $30.5 \%$ have experienced at least one physical violence that they consider to be serious;

. $31 \%$ have experienced sexual violence or rape;

. $22.5 \%$ had sought refuge in drugs or alcohol and felt "addicted" to their substance ..., before their radicalization.

This young radicalized future could not be considered victims because the entourage, society, justice, had ignored what they had lived. Thus the radical group has all the more easily offered the young a compensatory solution of recognition, support, revaluation, repair, etc.

-a trauma that took place during his/her radicalization: the trauma can also come from videos watched during radicalization. Many psychologists believe that the viewing of many scenes of extreme violence on the Internet can be a trauma.

- But it can also come from the radical group: some young girls were abused sexually or not, when they started to go around with some radical group members;

-a trauma once they were engaged: the trauma was caused by them. For example, the young radicalized-one had denounced someone who was whipped or killed; he/she had indoctrinated a younger-one who left on war zone and was killed, etc. In this case too, the social worker will have to make him/her recognize his/her share of "victimhood" in this type of behavior through which he/she now considers himself/herself as "a monster".

The fact of not being reduced to his/her actions, the fact of being a "victim" in the eyes of the social worker allows the radicalized-one to remember the part of humanity that is still in him/her, and then to assume his/her responsibility. Recognize themselves as victim and as author goes through an external and internal work. The recognition of the "perpetrator-victim" status also affects judicial processing

For example, when our work showed that girls were more easily removed from radicalization than boys [17] we were able to analyze that this difference was largely explained by social perceptions of their share of "victimhood" [11]. Indeed, representations and stereotypes related to gender of some institutional workers encourage them to better consider the complexity of the engagement of girls and to mandate a quasi-automatic psycho-educational follow-up (which appears to be one of the guarantees of radicalization's exit [11]. In fact, the police authorities require more multidisciplinary "exit from radicalization" treatment for girls than for boys.

We can make the hypothesis that sexual representations interact in the analyze of radicalized people cases: boys are perceived as more violent than girls, and therefore less easy to "un-radicalize". The police or prefecture departments have more confidence in girls to reintegrate society and question themselves about their radicalism. A girl is seen as someone who will harm herself: "surrogate mother" within the group, submissive wife and devoted to her husband locked inside her home, etc. A boy is perceived as someone who can hurt others: use bombs, attack physically someone, etc.

Therefore, the anti-radicalism cells of the police prefectures tend to transmit more "girls files" to field workers and more "boys files" to specialized police services. For the same reason, girls are also less easily indexed as "jihadists" than boys. Institutions will more easily diagnose them as "nonviolent radicalized" (pietist Salafists) or in adolescence crisis (with the need to break free from their mother for example). More evidence is needed for institutions and authorities to validate the diagnosis of "jihadist" for a girl. For example, watching a ISIS's propaganda video can be seen as a proof of a membership to the "jihadist" project for a boy, and as an indoctrination tool for the girl. The boy, for the same facts, will be "suspected violent".

5.2 - The care of children under 12 years old goes through the acknowledgement of their trauma and the upgrading of their potential

The care of children under 12 years old differs from the care of the older ones. The individualization of care will depend on the path and state of the child, on the level of radicalization of his/her family environment, on the information we have about his/her history, on his/her personal psychological and family characteristics (brothers and sisters), etc.

To evaluate the indoctrination's level of a child under 12 years old, it is a question of finding educational supports which will reinject complexity in his/her everyday life, to check if the child accepts / handles this complexity (or not). Indeed, the totalitarian worldview encloses people in a binary logic. There is never any scale, any action is measured in alternative terms: yes or no (knowing), for or against (belief), good or bad (moral). It is this binary logic that leads to a break with "others".

It is up to professionals to not repeat this kind of relationship with these young people: everything that would be in the realm of power and knowledge would lead unintentionally to have a line that would look like to the radical line operating like this, and to strengthen it, by symmetrical effect. On the contrary, the educational objective is to propose an area of freedom where the young person can ask questions and find answers. The point is therefore to rekindle him/her by using sensation and feeling vein.

Practical experimentation can also be used to assess / check the radical worldview of the child (if there is one), and its level of severity. Use the fun to assess the indoctrination's level of the child also allows to present him/her new ways of thinking, new worldviews without urging him/her to choose between the world of his/her parents (so-called religious reference) and the world of school (reference, so-called scholar). By adding a new range to the parent's references, without criticizing them, the professional gives the freedom to all the children to question certain opinions and values of their parents without getting away from them.

The overall goal is to reassure the child so that he / she can trust adults again. To facilitate his/her rehabilitation, 
it is necessary to have an approach not limited by the work over the trauma experienced. Valuing everyone's potential appears to be a fundamental approach. The RAN states that "it is important to foster the development of fundamental points such as interpersonal skills, emotional management, stability of family life, etc., so these children can have the opportunity to contribute positively to society" [28].

5.3 - The family, is the base of the care for the 0 to 18 years old?

Recreating family ties was part of denazification. Indeed, after the war, "the antifascists" describe the hell of Nazism as an aggression of the individual and the family. We have seen, through the first parts, that the break with the nonradicalized family is part of the first stages of the children and adolescent's recruitment. Among ISIS as in all other totalitarian ideologies, children have gone so far as to denounce their own father. Even when the family is radicalized, the radical group takes over the biological family anyway. The leader becomes the father.

The radical group, in any case, becomes a substitution group that destroys the individuality of the recruits to strengthen the fusion within the group. The place of the family, in care process, therefore, appears as a fundamental parameter.

-Should we use the extended non-radicalized family when the parents are incarcerated?

-When the parents come out prison, when can the child be handed over to them?

-Is the foster family better than the educational home?

-Etc.

The break with the family does not facilitate the exit of children from radicalization. The RAN has repeatedly pointed out that family separation makes difficult the care of children. The RAN report recommends that child custody can be offered to the child's non-radicalized family.

The feeling of abandonment is not the only negative consequence of a family separation. Family support will also help when social workers will start to lead the child or adolescent to question his /her certainties about the definition of his/her group (those who will save the world) and the definition of "others" (the non-believers who want to eradicate Muslims because they know that they (Muslims) have the solution to save the world). We can call it "unradicalization" "disengagement", "free will work", "youth empowerment", it does not matter... Still, the psychoeducational work will question the worldview inculcated to the minor underpinning his/her presence in Syria, the violent actions of adults, and now the incarceration of the parents...

If we refer to our 12 years old follow-up experience, the role of the extended family, including non-radicalized grandparents is fundamental to the process of re-affiliation. This mainly concerns the recall of the old cues erased by the indoctrination: affective, historical, memorial, etc. The "jihadist" line operates a disaffiliation of the individual by putting him/her in a substitution's community and giving him/her the illusion of belonging henceforth to a sacred mythical lineage. If the whole family does not toggle together in this new identity, the radical line multiplies the arguments to create a break with the original family. During the follow-up of the young person, the extended nonradicalized family occupies a privileged symbolic place to restore the old identity cues erased by the indoctrination and revive the founding elements of the history of the young person.

Thanks to statistics made from the two-years follow-up of 450 jihadists [17], we can affirm scientifically two results:

- the reassuring relational approach is a condition for any cognitive and ideological work in the process of disengagement;

- the family is the better to implement this "reassuring relational counter-approach", against the anxiety approach put in place by the jihadist line. Indeed, the statistics show that our failures (20\% of our sample) was made up by $65 \%$ of adults and $35 \%$ of minors [17]. They prove the effectiveness of the reassuring emotional approach implemented with the families, preliminary step of the disengagement cognitive remobilization [17] .

Learn to diagnose the connection between family and the "jihadist" ideology must therefore become a priority, so to not automatically separate the children from their grandparents, but also to respond to the judge's requests when they ask the social workers about the possibility of returning the children to the parents when they will live prison.

\section{CONCLUSION:}

Our experiences have taught us that de-radicalization programs and studies have not sufficiently explored the link between the emotional dimension and the ideological dimension. This might be due to the fact that observers haven't had access to "the small steps in process of the radicalization" of the child, nor to his "invisible threads" and "implicit motives." Only $31 \%$ of the world's research on terrorism has been able to use empirical data [36].

By studying our data, we became aware of the fact that the rejection of "the Other" and of Western democracies is caused simultaneously by both the ideology and the emotional anxiety-inducing approach of the jihadists. All young people that we studied have experienced some sort of obsessive anxiety about everything related to the human experience that was conveyed to and shared with the group, while supporting an ideology according to which everything related to the human experience is tantamount to betraying the oneness of God. It is the mixture of ideology and strong emotional reactions that, from our point of view, causes violence.

This also means that the cognitive opening of the radicalized is dependent on relating the emotional approach to the ideological approach. Even if the radicalization process is based on ideology that provides a binary worldview, one cannot challenge it with knowledge and reasoning [15]. It is counterproductive to directly confront the youth since this will automatically make them suspicious towards anyone outside the radical group. Furthermore, prior work shows that the counter-narrative itself does not achieve much [36]. 
The goal is to challenge the cognitive aspect. However, the cognitive approach is not possible without the emotional approach. This validates our hypothesis that as the jihadist discourse combines emotion and ideology in their approach to gain supporters, the actors who want to fight against this phenomenon must also adopt this two-fold approach, with the help of relatives (See diagram below). To sum up, to successfully combat the ideology and the jihadist group, the conceptual framework for the disengagement program must integrate this two-fold emotional-ideological dimension.

Acknowledgments: We thank the CPDSI team and Bouzar-Expertises team for contributing to all the reflections that are shared and analyzed here. In particular, we thank Sûleyman Valsan who has researched about the other totalitarian movements.

Conflict of Interest: The authors declare no conflict of interest.

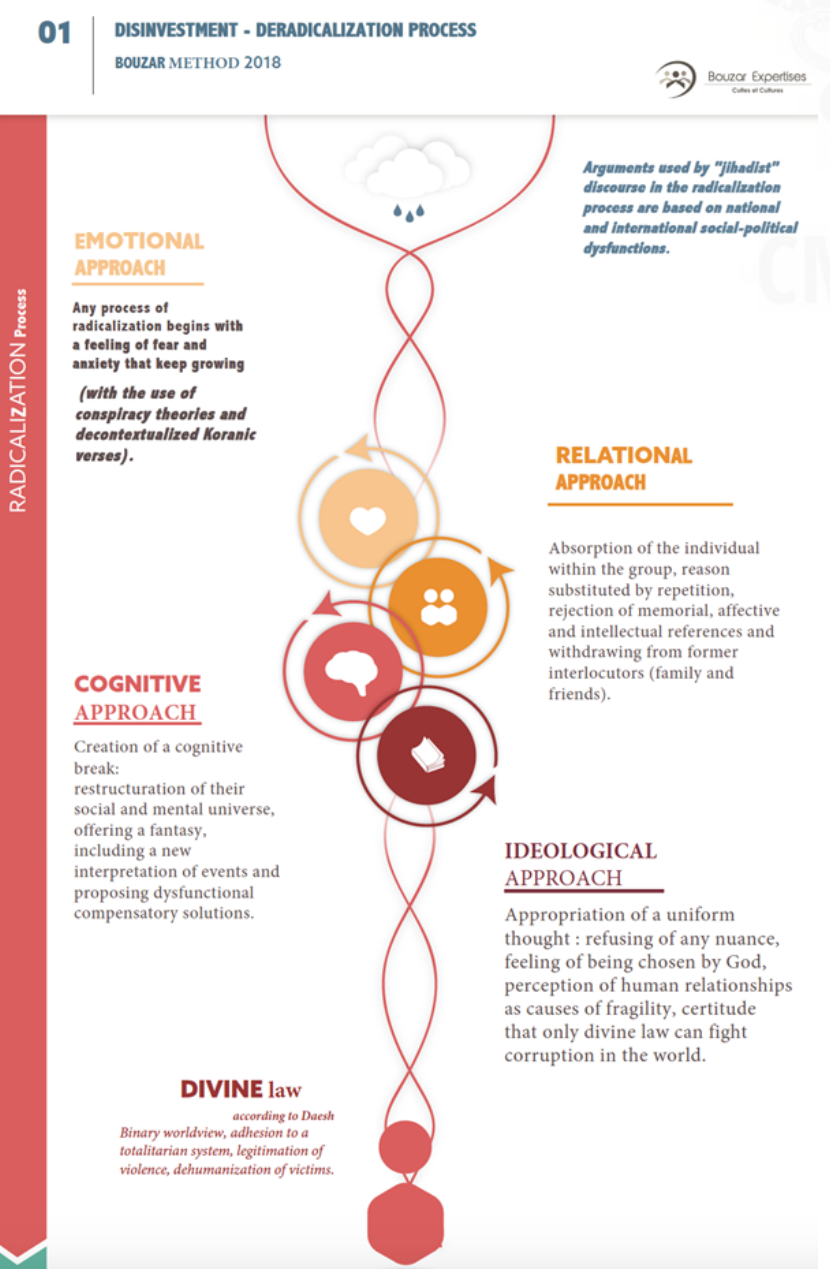

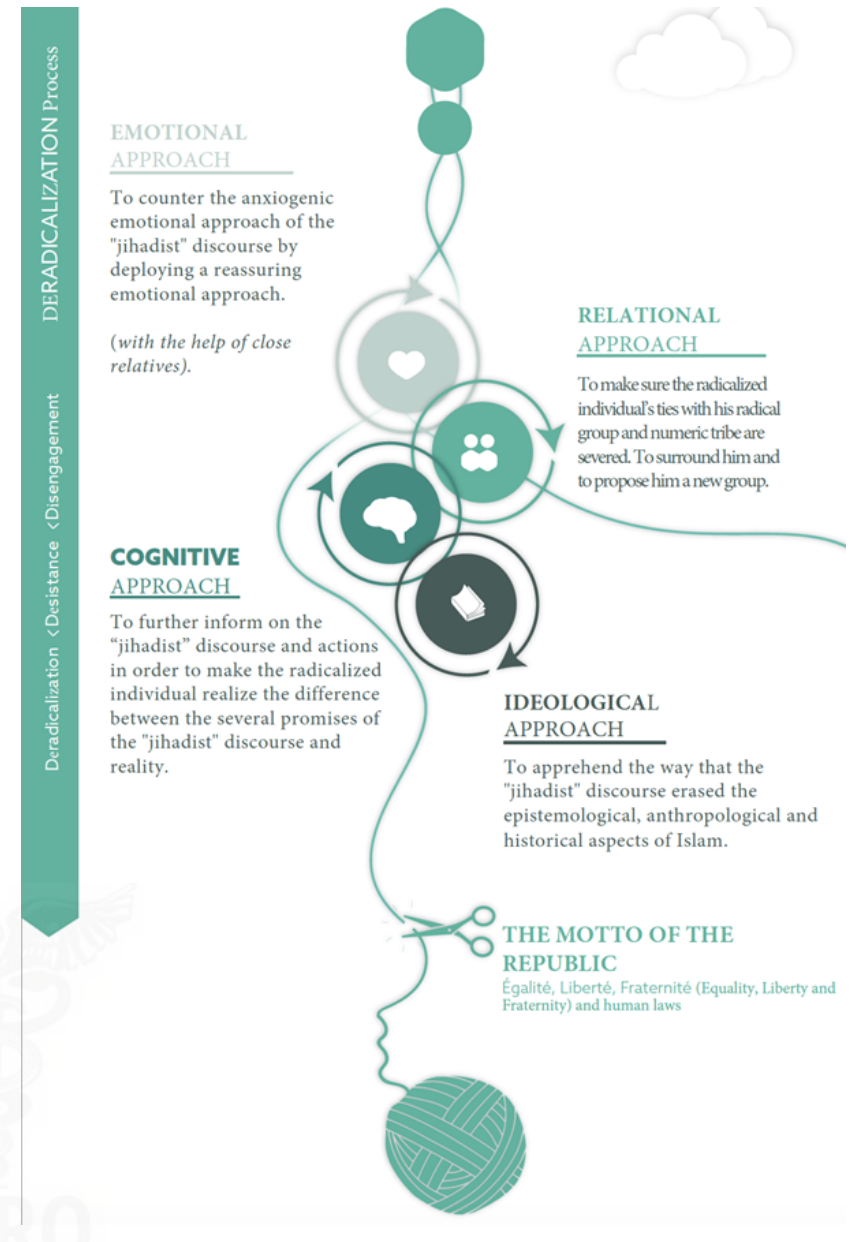

Source : Cabinet Bouzar Expertises/Practicies.

\section{REFERENCES}

[1] BOUZAR D, « La mutation du discours djihadiste : les nouvelles formes de radicalisme musulman (the mutation of the jihadist line : the news shapes of the muslim radicalism; In «La radicalisation violente » (the violent radicalization), Cahiers de la Justice et de la Sécurité $n^{\circ} 30$; Paris, INHESJLa Documentation française; 2014.

[2] DUCOL B, « Devenir djihadiste à l'ère numérique : une approche processuelle et situationnelle de l'engagement djihadiste au regard du Web» (Become jihadist in the digital age: a processual and situational approach of the jihadist engagement in the light of the web) (doctoral thesis). Laval: University of Laval; 2015.

[3] al PAUWELL. " Comprendre et expliquer le rôle des nouveaux médias sociaux dans la formation de l'extrémisme violent, Une recherche qualitative et quantitative » (Understand and explain the role of new social media in the formation of violent extremism. A qualitative and quantitaive search). Bruxelles: Belspo; 2014.

[4] HUSSEIN H, « Le recrutement numérique des adolescent.e.s par ISIS : les chants "anasheed" djihadistes » (Digital recruitment of teenagers by ISIS : jihadists songs « anasheed »). Mediadoc. 2017 6;18. 
[5] ALAVA S. "Les réseaux sociaux et la radicalisation des jeunes à l'ère du numérique». Information and Communication Sector. 2017;

[6] all CONESAP. « La propagande francophone de Daech : la mythologie du combattant heureux » (The french ISIS propaganda : the mythology of the happy soldier). FMSHFAVT; 2017.

[7] BAUDIS D, Préface. In KEYSERS R, L'enfance nazie (The nazi childhood). Paris: L'Harmattan edition; 2017.

[8] Fondation Quilliam, Les enfants de Daesh (Children from ISIS). London: Inculte; 2016.

[9] BOUZAR D, CAUPENNE C, VALSAN S, La métamorphose opérée chez le jeune par les nouveaux discours terroristes (The metamorphosis operated over young people by the new terrorist lines). CPDSI; 2014. Available from: www.bouzar-expertises.fr.

[10] CAMPELO N, BOUZAR L, OPPETIT A, HEFEZ S, BRONSARD G, COHEN D, BOUZAR D, Joining the Islamic State from France between 2014 and 2016: an observational follow-up study; 2018. Paris: Palgrave Communications;

[11] Facteurs de risque et de protection facilitant le désengagement de l'extrémisme violent djihadiste : études sur les variables de devenir de 450 djihadistes. BOUZAR D \& BÉNÉZECH M. 2019;

[12] Dunod, editor. BOUZAR D, Which education in face of religious radicalism?; 2016.

[13] Reaching the parts other methods cannot reach: An introduction to qualitative methods in health. POPE C \& MAYS N. 1995;p. 311-42.

[14] What motives bring youth to engage in the Jihad? Neuropsychiatr Enf Adolesc. BOUZAR D \& MARTIN M;.

[15] BOUZAR D, A Novel Motivation-based Conceptual Framework for Disengagement and De-radicalization Programs. Sociology and Anthropology; 2017.

[16] PAXTON R, The anatomy of fascism. Paris : Editions du Seuil coll. « Points. Histoire» (Translated by; 2007.

[17] BOUZAR D, Français radicalisés, l'enquête (French radicalized, the inverstigation), Ivry/seine : Editions de l'Atelier; 2018.

[18] BOUZAR L, The Disengaged (Young people's white paper followed by the CPDSI), Extract from Aline's testimony; 2017. Available from: www.bouzar-expertises.fr.

[19] HOFSTADTER R, The Paranoid Style in American Politics and Other Essays. New York: Vintage Books; 2008.

[20] T BECKA. Prisonniers de la haine, les racines de la violence, (translated by Jean Cottraux, with the collaboration of Héloïse DUPONT and Maud MILLIERY). Paris: Edition; 2002.

[21] de la psychologie et de la psychiatrie dans la connaissance des phénomènes de radicalisation et de terrorisme. Cahiers de la Justice et de la Sécurité nº33; Paris, INHESJ-La Documentation française. BÉNÉZECH M \& ESTANO N, L'apport. 2016;.

[22] FREUD S, Psychologie des foules et analyse du Moi (Crowd psychology and ego analysis). Paris : Petite. de; 2012. .

[23] KELMAN H, «Violence without Moral Restraint: Reflections on the Dehumanization of Victims and Victimizers ». Varieties of Psychohistory;1976(29):25-61.

[24] S. Soumission à l'autorité; 1974.

[25] ASCH S, Effects of group pressure upon the modification and distortion of judgments. Pittsburgh, PA: Carnegie Press; 1951.

[26] BROWNING C, Des hommes ordinaires : Le 101e bataillon de réserve de la police allemande et la Solution finale en Pologne (Ordinary Men: 101st German Police Rescue
Battalion and Final Solution in Poland). Paris:Les Belles Lettres; 1994.

[27] HAMILTON C. Report "Children and counter-terrorism", United Nations Interregional Crime and; 2016.

[28] Radicalisation Awareness Network; Available from: https://ec.europa.eu/home-affairs/what-we-do/networks / radicalisation_awareness_network_en.

[29] KALONGA A, MAZOMBA L, « Désarmement, démobilisation et réintégration, échec au Sud Kivu ? (Disarmament, demobilization and reintegration, failure in the South Kivu ?); 2016 .

[30] International Convention concerning child rights (CIDE). New York Convention, signed in; 1989. Available from: https://www.google.com/search.

[31] Protocol Additional to the Geneva Conventions of $12 \mathrm{Au}$ gust 1949, and relating to the Protection of Victims of NonInternational Armed; 1977. Available from: databases.icrc. org/ihl/WebART/475-760008.

[32] Optional Protocol to the Convention on the Rights of the Child on the Involvement of Children in Armed Conflict (OPAC), signed 25; 2000

[33] Office of the Special Representative of the Secretary-General for Children and Armed Conflict, Working paper $\mathrm{N}^{\circ} 3$ "Children and Justice During and in the Aftermath of Armed Conflict". New York: United Nations; 2011. Available from: http://childrenandarmedconflict.un.org.

[34] BRETT R, Justice pour mineurs, lutte antiterroriste et enfants (Juvenile justice, counter-terrorism and children); 2002. Quaker office at the United Nations. Available from: http://www.quno.org/resource/2002/11/ juvenile-justice-counter-terrorism-and-children.

[35] MOUZAYAN O, L'enfant soldat. Paris: Edition Odile Jacob; 2003

[36] Rapport international sur la prévention de la radicalisation violente: une étude internationale sur les enjeux de l'intervention et des intervenants (International Report on the Prevention of Violent Radicalization: An International Study on the Issues of Intervention and Stakeholders). Montréal, Canada: Centre: International de Prévention de la Criminalité; 2017. 